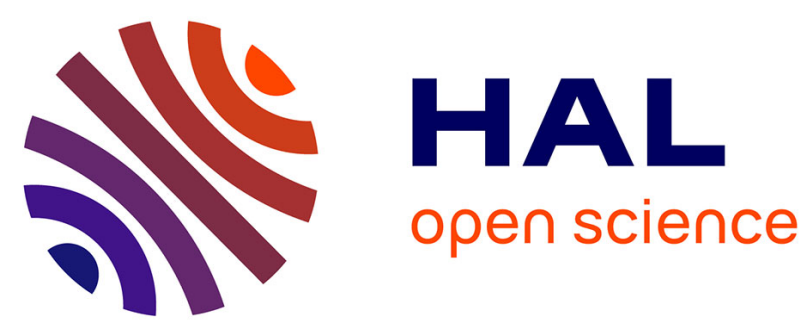

\title{
Biodiversity in salt marshes: from the patrimonial value to the ecosystem functioning. The case study of the Mont Saint-Michel bay.
}

Jean-Claude Lefeuvre, Pascal Laffaille, Eric Feunteun, Virginie Bouchard, Alain Radureau

\section{To cite this version:}

Jean-Claude Lefeuvre, Pascal Laffaille, Eric Feunteun, Virginie Bouchard, Alain Radureau. Biodiversity in salt marshes: from the patrimonial value to the ecosystem functioning. The case study of the Mont Saint-Michel bay.. Comptes Rendus Biologies, 2003, Vol. 326, pp.125-131. 10.1016/S16310691(03)00049-0 . hal-00793409

\section{HAL Id: hal-00793409 \\ https://hal.science/hal-00793409}

Submitted on 22 Feb 2013

HAL is a multi-disciplinary open access archive for the deposit and dissemination of scientific research documents, whether they are published or not. The documents may come from teaching and research institutions in France or abroad, or from public or private research centers.
L'archive ouverte pluridisciplinaire HAL, est destinée au dépôt et à la diffusion de documents scientifiques de niveau recherche, publiés ou non, émanant des établissements d'enseignement et de recherche français ou étrangers, des laboratoires publics ou privés. 


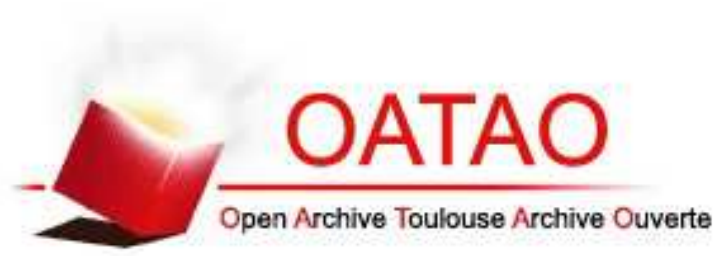

\section{Open Archive Toulouse Archive Ouverte (OATAO)}

OATAO is an open access repository that collects the work of Toulouse researchers and makes it freely available over the web where possible.

This is an author-deposited version published in: http://oatao.univ-toulouse.fr/ Eprints ID: 6177

To link to this article: DOI: DOI:10.1016/S16310691(03)00049-0

URL: http://dx.doi.org/10.1016/S1631-0691(03)00049-0

To cite this version: Lefeuvre, Jean-Claude and Laffaille, Pascal and Feunteun, Eric and Bouchard, Virginie and Radureau, Alain Biodiversity in salt marshes: from the patrimonial value to the ecosystem functioning. The case study of the Mont Saint-Michel bay. (2003) Comptes Rendus Biologies, Vol. $326\left(\mathrm{n}^{\circ}\right.$ 1). pp. 125-131. ISSN 1631-0691

Any correspondence concerning this service should be sent to the repository administrator: staff-oatao@ listes-diff.inp-toulouse.fr 


\title{
Biodiversity in salt marshes: from patrimonial value to ecosystem functioning. The case study of the Mont-Saint-Michel bay
}

\author{
Jean-Claude Lefeuvre, Pascal Laffaille ${ }^{*, 1}$, Eric Feunteun ${ }^{2}$, Virginie Bouchard ${ }^{3}$, \\ Alain Radureau
}

UMR 6653 EcoBio, Equipe d'animation de la zone atelier "La Baie du Mont-Saint-Michel et ses bassins versants», Université de Rennes 1, Campus Beaulieu, 35042 Rennes cedex 1, France

\begin{abstract}
Until 1979, European salt marshes were known only through the inventories of fauna and especially of flora. On such criteria, the salt marshes of the Mont-Saint-Michel bay (France) were regarded as most significant of the French coasts. However, it took 20 years of research on the role of these wetlands of the estuaries-salt marsh systems to highlight the ecological, social and economic interest of this ecotone, between continental and marine systems, a long time considered as territory "without value", except for stock breeders or hunters. To cite this article: J.-C. Lefeuvre et al., C. R. Biologies 326 (2003).
\end{abstract}

\section{Résumé}

Biodiversité dans les marais salés : de la valeur patrimoniale au fonctionnement de l'écosystème. Le cas de la baie du Mont-Saint-Michel. Jusque dans les années 1979, les marais salés européens n'ont été connu qu'à travers des inventaires de faune et surtout de flore. Sur ces critères d'inventaire, les marais salés de la baie du Mont-Saint-Michel (France) ont été considérés comme les plus importants des côtes françaises. Mais, il a fallu 20 ans de recherche sur le rôle des zones humides des systèmes estuaires-marais salés pour mettre en évidence l'intérêt écologique, social et économique de ces espaces de transition entre terre et mer, longtemps considérés comme des territoires «sans valeur», hormis pour les éleveurs ou les chasseurs. Pour citer cet article : J.-C. Lefeuvre et al., C. R. Biologies 326 (2003).

Keywords: wetland; functional biodiversity; intersystems exchanges; food web; human activities

Mots-clés : zone humide; biodiversité fonctionnelle ; flux intersystèmes ; réseaux trophiques ; activités humaines

\footnotetext{
* Corresponding author. E-mail address: plaffaille@hotmail.com (P. Laffaille).

1 Present address: Laboratoire d'Ecologie Animale, Faculté des Sciences, Université d'Angers Belle-Beille, 49045 Angers, France.

2 Present address: Laboratoire de Biologie et Environnement Marin, Université de La Rochelle, 17000 La Rochelle, France.

3 Present address: School of Natural Resources, The Ohio State University, 2021 Coffey Road, Columbus, OH 43210, USA.
} 


\section{Introduction}

Wetlands are complex ecosystems, which form an interface between terrestrial and aquatic habitats. In this extent they are typical "ecotones", which were recently defined as "transition zones between adjacent ecological systems, having a set of characteristics uniquely defined by space and time scales, and by the strength of the interactions between adjacent ecological systems" [1]. Therefore, these ecotones are shown to be highly sensitive to environmental changes. The species forming the communities of ecotones are either generalists coming from adjacent systems or specialists which are adapted to the specific ecological conditions prevailing. Whatever the origin of these species, they have strong physiological capacities to support particular environmental conditions of ecotones as wetlands. For these reasons, wetlands are good places to evaluate the intensity and importance of global change. Monitoring ecotones therefore provides means to detect, for example, immediate biotic responses to climatic changes [2].

Unfortunately wetlands account among most threatened ecosystems of the world. In the 1960s, international organisations drew attention to their rapid regression, mainly due to land reclamation and major degradation caused by industrial or urban pressures. Indeed, the policies of numerous countries encouraged or even funded the conversion of wetland for agriculture, urbanism, port and industrial development, a range of activities, which culminate with a destruction of wetlands. The national research council then estimated that the federal policies, in addition to extensive private efforts of a similar nature, reduced the total wetland acreage in the contiguous United States by approximately 117 millions of acres representing half of the original total by mid-1980s. An evaluation of public environmental policy showed that half of them have disappeared since 30 years and that this trend is still continuing [3]. This fact is overwhelming considering the action of international organisations ended up with the MAR project (such as Marais, Marismas, Marshes) and the ratification of the Ramsar convention in 1971 for the protection of wetlands. Unfortunately this convention mainly focussed on the conservation of water birds, which were long used as the only criterion for wetland assessment. This apparent disjunction between the acknowledgement of wetlands, their high conservation status ratified by 180 countries and their continuous destruction seems due to the fact that the value of wetlands has mainly been assessed through their specific richness and their biodiversity, which simply describes a patrimonial value [4]. Development of investigations on the ecological functioning of these particular ecosystems, and their role on the control of the transfer and exchanges between terrestrial and aquatic systems was only taken into account very recently. European research conducted by $[5,6]$ actualised North American research developed in the 1960 s $[7,8]$ on the role of salt marshes on the ecological functioning of salt marsh-estuarine and coastal ecosystems. An European Union funding supported several research projects that showed the ecological interest of salt marshes and, in conclusion, demonstrated the social and economical importance of these areas long time considered as valueless, except for game and agricultural interests. In France, research has been conducted since 1979 in the Mont Saint-Michel bay $[9,10]$.

In this context, we propose to analyse respective interests of patrimonial biodiversity and functional biodiversity approaches. To this aim, we will base our analysis on our research experience on salt marshes of Mont Saint Michel Bay in France.

\section{From the concept of biodiversity in wetlands...}

The concept of biodiversity is broad and is still evolving [11]. In wetlands, analysing biodiversity is particularly difficult compared to many terrestrial or coastal environments [4]. Late in the nineteenth century, F.E. Clements realized that the transition zones between plant communities had properties distinct from either of the adjacent communities [12]. This observation was used much later when the wetlands began to be studied as original ecological entities characterised by fuzzy limits integrated in a spatial and temporal continuum from terrestrial to aquatic environments [4].

The presence of vegetal species adapted to high temporal or permanent humidity of hydromorphic soils, or to variable flood periods is now used as the most convenient criterion to define spatial limits of wetlands. In tidal salt marshes, the plant communities are structured by both ambient salinity levels and the degree of flooding stress, determined to a large extent 
by elevation of the marsh and tidal inundation rates. Considering salt marshes are isolated entities, the island theory [13] is generally applicable: the specific richness of plants depends upon their size and their respective remoteness [14]. Thus, the salt marshes of Mont Saint-Michel Bay contains $64 \%$ of the total number of halophytic species listed in French coasts because they are one of the largest salt marsh of the French Atlantic coast with an area of 4000 ha, and because they are located at the southern or occidental distribution limit of many species [15]. Therefore, with reference to its 67 plant species, the Mont SaintMichel bay presents the highest patrimonial value in France.

In turn, the diversity of halophytic communities originates a number of habitats, which confer a high hosting and trophic capacity for many animal species [4]. Nevertheless, only a few numbers of resident species are able to spend their whole life cycle in wetlands. This number varies among groups: it is relatively high in arthropods but low in vertebrates. For the latter, most species are transient, i.e. they colonise temporarily these transition habitats, either during migrations or during a key period of their life cycle as migration stops, resting or feeding periods [16]. Most species come from adjacent terrestrial or aquatic environments. The resulting specific richness due to strict residents and transients varies both in time and space, especially according to seasons and tidal flooding. For some aquatic animals, and mainly for fish, the colonisation of the marshes is only possible during very short temporal windows, which correspond to flooding periods [17]. If we sum up the flux of species throughout a whole year, the global diversity of wetlands is relatively high, but it is generally low if one only considers a short period of the year, because all species do not occur in the salt marshes during the same temporal windows. Another problem is due to the difficulty of distinguishing the origin of the species: do wetlands act as source or well environments according to Dias's definitions [18]? Moreover, the lack of complete inventories for some lowly studied groups such as arthropods makes comparisons difficult. In France, the only reliable studies were made in the salt marshes of Arcachon bay [19], in the bay of Somme [20] and in the Mont Saint-Michel bay [21]. Elsewhere, and despite the quality of this research, whole groups such as nematodes or phytophageous species like heteropteres were neglected. All these facts clearly show the difficulty to assess the biological diversity by considering only the specific richness.

Among transient species, the case of water birds deserves particular attention. Most of them only use salt marshes temporarily during migration stops for wintering. For the Ramsar convention (1971), the numeric distribution of water birds is used as an assessment of the importance of wetlands. This method was based on the percentage of birds wintering or breeding in a given wetland compared to the total regional, national or worldwide population size. The interest of this method is that it obliged countries to perform simultaneous counts in all the wetlands each year. The drawback is the difficulty to interpret inter annual variations of anatid and waders population sizes in wetlands; this variations being likely caused either by wetland degradation or to adjacent environments or to climatic variations occurring in other regions used by the birds [22]. For example in Mont Saint-Michel Bay, the numbers of Anas penelops varies from zero during mild winters in northern Europe to over 25000 birds when winters are cold in the same region [23].

Despite the weakness of these inventories, and the related interpretation difficulties of the biodiversity surveys in ecotones, one must recognize that such assessments have permitted the listing of Mont SaintMichel Bay among the world heritage of the UNESCO in 1979, creation of coastal game reserves in 1967 , 1973 and 1974, obtaining of a set of conservation labels as Ramsar, ZNIEFF (area of national ecological, botanical and zoological interest), ZICO (area of regional interest for bird conservation), Natura 2000 site, etc. Nevertheless, despite all these protection measures and the well-described floristic and faunistic patrimonial interest of salt marshes, one of the first projects to control the extension of salt marshes took place in the Mont Saint-Michel Bay. It mainly planned to destroy about $25 \%$ of the wetland surface by building 3 dams. Despite official interdictions, salt marshes are more and more used as car parks in Summer; the high marsh is mowed earlier and earlier in the summer while a conservation plan of Cotrinux cotrinux recommended to postpone this activity until late summer; part of the salt marsh is over loaded with sheep creating a monospecific Puccinelia maritima plant community. The objective of this paper is not to deny the interest of species inventories in wetlands. 
The high importance of such monitoring of wetlands is undeniable. However, it seems that an approach of functional biodiversity appears to be more pertinent.

\section{3. ... to functional biodiversity}

The massive loss of species and ecosystems, and especially wetlands and associated organisms [24], creates an urgency to investigate the roles of biodiversity in the functioning of ecosystems $[11,25]$ and more generally shifts in ecosystem functioning provoked by various human uses of natural resources. Various hypotheses were developed to explain relations between specific richness and their role in the functioning of ecosystems. The most debated one is certainly the diversity-stability hypothesis [26]. But during the 1990s, two simultaneous studies highlight that the systems hosting most diversified primary producers communities are also the most productive [27, 28]. Despite the controversies they involved, these studies enabled the development of a modern "functional diversity" concept that is defined as "the variety of different responses to environmental change, especially the diverse space and time scales with which organisms react to each other and to the environment" [29]. Thus beyond the richness of species, it is indispensable to distinguish the functional role played by each of these species. Moreover, in many cases, the observed specific richness is thought to be superior to that needed to ensure any given ecological function. This suggests that a functional redundancy exists among species, which ensures similar functions. Considering that it is rarely possible to determine precisely such relative contributions, functional groups or guilds are described as exerting comparable actions on a given process.

For example, vegetal communities of salt marshes are spatially distributed according to physical and biotic factors, which are tightly linked to the marsh's topography which determines the frequencies and durations of tidal submersion, physical and chemical characteristics of the soil and interspecific competition conditions. In the Mont Saint-Michel Bay, the 67 censured halophytic species are clustered spatially in four distinct zones: a pioneer zone dominated by Salicornia spp. and Spartina spp., low marshes with Puccinelia maritima and Atriplex portulacoides, middle marsh with Atriplex spp. and high marshes with
Elymus athericus and Festuca rubra [10]. In many cases, the present observable zonation is a result of past vegetation succession. Indeed, the relation between zonation and succession is linked to the geomorphogenesis of salt marshes [30]. A pioneering salt marsh traps sediment. The progressive accretion involves a shift of the halophytic associations seawards. According to this model, a high marsh is originated by a low marsh and, if the accretion process continues, the actual low marsh will finally become a high marsh hosting species adapted to infrequent flooding. Thus, the evolution and the maturation of the salt marshes may be analysed by the observation of these four halophytic associations. But these plant communities also play different roles for the ecological functioning of salt marshes and adjacent coastal areas. In fact, salt marshes are among the most productive systems of the biosphere: the primary production that may attain over 30 tons of dry organic material $\mathrm{ha}^{-1} \mathrm{y}^{-1}$ provides an abundant necromass. Since the development of the outwelling concept $[7,8]$, which states that tidal events export detritical organic material produced in salt marsh to marine water, strong evidence also indicates that the export of organic matter from terrestrial to aquatic systems consequently supports secondary production. In natural salt marshes, the plant diversity and NAPP (Net Aerial Primary Production) varies according to marsh maturity. The diversity tends to decrease from the low marsh (community dominated by 4 or 5 species) to the high marsh community (dominated by 2 species), whereas NAPP follows an opposite pattern (from 5 tons in the lower marsh to 20 tons $\mathrm{OM} \mathrm{ha}^{-1} \mathrm{y}^{-1}$ in the high marsh) [10].

However, in the world, most wetlands are exploited for agricultural purposes. One of the most common is the exploitation of the primary production by domestic stock grazing [31]. The impacts of herbivores on diversity of primary producer are well documented [32, 33]. Generally, ungrazed grassland communities are dominated by a low number of competitive species. Moderate grazing increases structural diversity by creating mosaics of grazed and ungrazed patches, which enhances plant diversity. Intensive grazing, which occurs in many agroecosystems, favours the dominance of a few species tolerant to trampling, and in most intensive situations, overgrazing provokes total or partial destruction of the topsoil and associated plants. With the presence of sheep in the salt marshes of 
the Mont Saint-Michel Bay, a much less productive plant community (dominated in Europe by Puccinellia maritima) replaces original salt marsh vegetation. This community and the associated relatively low productivity are a known consequence of grazing by herbivorous species in many European salt marshes $[10,31,32]$. This change of vegetation favors wintering anseriforms (Anas Penelope and Brenta bernicla) [34].

According to the outwelling hypothesis, organic matter is transferred directly as macrodetritus or indirectly after degradation by micro-organisms as particulate organic matter, dissolved organic matter and nutrients towards coastal waters $[7,8,10]$. The transfer of organic matter and nutrient is a source of enrichment of mud flats and explains partly the high productivity of the mud flats colonised by diatoms. Transport is either physical (i.e., tidal currents, groundwater, and atmosphere), which constitute abiotic vectors. The consequence of intensive sheep grazing is that grazing indirectly modifies soil microbiological processes, which affects nitrogen and carbon cycling and decreases the potentiality of organic matter and nutrient exports by physical vectors [10]. Although fluxes by physical vectors can be significant, transfer of organic matter is also facilitated by trophic migration of aquatic fauna such as fish communities [35], which constitute biological or biotic vectors [36]. In salt marshes, fish communities colonise this wetland during flood, ingest great quantities of live and detritic organic matter that they export towards adjacent coastal waters in different ways (mainly as fauna stomach content and body weight) [37]. This predation in salt marshes by juvenile sea bass (Dicentrarchus labrax) during the 'diet season' (from March to November) is sufficient to explain from $40 \%$ to $60 \%$ of the growth [38]. By changing the salt marsh vegetation, intensive grazing indirectly reduces the density of prey exploited by fish and consequently reduces the trophic function of wetland for the aquatic fauna [39].

Our team surveys, relatively accurately, progression and transformation processes of the Mont SaintMichel Bay salt marshes since 1984 when the first vegetation map was designed [40]. This survey highlighted radical changes of the vegetation cover in the salt marsh due to a rapid invasion by Elytriga spp. $[40,41]$. This poacae is normally confined in the high marsh, tends to invade the lower parts of the marsh at least since 1990 [40]. Progressively, in some areas of the Mont Saint-Michel Bay, this species has extended threefold its area within only 10 years and has replaced middle marsh Atriplex communities [41]. Such a progression is characteristic of invasive species [42]. The entire ecological functioning of the area is likely to be disturbed, in particular because the organic matter flux processes between salt marshes and coastal waters are modified and the whole food web is also unbalanced. For example, several functions of the salt marshes may be modified by such an invasion: the exportation capacity of the salt marsh could be modified and in turn effect mussel and oyster culture with linked economical consequences; the habitat value for anatids and other game birds and the nursery function for fish species could be changed.

\section{Conclusion}

Thus, the biodiversity concept progressively changed from an "account" conception to a integrative approach of the global functioning of the ecosystem, and even of ecosystem complexes in a given territory. Thus, in order to appreciate the biodiversity in a given system or territory, it is not only required to have a good knowledge of all the hosted species but also to know its ecological functioning modalities and processes. Paradoxically, the direct consequence of the increasing complexity of the notion of biodiversity is that it is only possible to analyse functional biodiversity through a few number of particular functional aspects that have to be integrated in a more general context.

Considerable effort is still to be spent in order to produce an exhaustive description of biodiversity in most wetlands. We emphasize that good specialists of systematics are lacking: some difficult groups are poorly studied while their key functional role is known, as for nematodes. It is thus necessary to increase knowledge about systematic of species but also to better understand their functional role, which represents the only approach enabling us to link natural richness and human society through notions of natural services and sustainable resources.

Elsewhere, it is necessary to better analyse the role wetlands play for biodiversity conservation, from the local scales of the studied areas to the regional scale of the whole hydrosystem, or of the distribution range 
of the species. For example the number, spatial organisation and surface of wetlands necessary to maintain populations at sustainable levels for game, fishing and agriculture are poorly analysed. Conversely, it is necessary to better understand the effects of wetland losses not only on the biodiversity, but also on the hosting capacity for some populations. For example, a peatland, backwaters, a floodplain or a marsh are not only interesting for themselves, but they have to be considered an elements of landscapes they belong to. Analyses must thus be performed simultaneously at various time and spatial scales.

Moreover, efforts to develop historical analysis need to be strengthened. Indeed, wetlands are intrinsically transitory environments which are bound to evolve more or less genuinely from aquatic to terrestrial habitats, and are submitted to stochastic variations due to climatic hazards. Such structural instability and variability must not be considered as a disturbance but, contrarily, as strong structuring factors, originating heterogeneity and thus biodiversity. This kind of approach is also necessary to develop prospective analyses: modelling possible trajectories of hydrosystems according to changing environmental conditions due to combined natural and human effects.

Analyses of biodiversity in wetlands must be expressed through comparative studies, not only diachronic, but also synchronic which are the only reliable bases enabling generalisation. Therefore, it imperative to step up systematic comparisons of some aspects of the biodiversity in wetlands. In particular, application of standardised methodologies remains rare, rendering comparisons difficult.

\section{Acknowledgements}

We thank many colleagues for their active cooperation in this research. This study was supported by EU funds (DG XII) and the CNRS (zone atelier PEVS "La Baie du Mont-Saint-Michel et ses bassins versants").

\section{References}

[1] M.M. Holland, SCOPE/MAB technical consultations on landscape boundaries: report of a SCOPE/MAB workshop on ecotones, Biology International 17 (1988) 47-106.

[2] A.J. Hansen, F. Di Castri, R.J. Naiman, Ecotones: what and why? Biology International 17 (1988) 9-46.
[3] P. Bernard, Les zones humides, rapport d'évaluation, Comité interministériel de l'évaluation des politiques publiques, Premier Ministre-Commissariat au Plan, rapport d'évaluation, la Documentation Française, Paris, 1994.

[4] E. Fustec, J.-C. Lefeuvre, et al., Fonctions et valeurs des zones humides, Dunod, Paris, 2000.

[5] W.J. Wolff, M.N. van Eeden, E. Lammens, Primary production and import of particulate organic matter on a salt marsh in the Netherlands, Nerth. J. Sea Res. 13 (1979) 242-255.

[6] N. Dankers, M. Binsbergen, K. Zegers, R. Laane, M. Rutgers, Transportation of water, particulate and dissolved organic and inorganic matter between a salt marsh and Ems-Dollard Estuary, the Netherlands, Estuarine Coastal and Shelf Science 19 (1984) 143-165.

[7] J.M. Teal, Energy flow in the salt marsh ecosystem of Georgia, Ecology 43 (1962) 614-624.

[8] E.P. Odum, A research challenge: evaluating the productivity of coastal and estuarine waters, in: Proceeding of the Second Sea Grant Conference, University of Rhode Island, 1968, pp. 63-64.

[9] J.-C. Lefeuvre, G. Bertru, F. Burel, L. Brient, V. Créach, Y. Gueuné, J. Levasseur, A. Mariotti, A. Radureau, C. Retière, B. Savouré, O. Troccaz, Comparatives studies on salt marshes processes: Mont Saint-Michel Bay: a multi-disciplinary study, in: W.J. Mitsch (Ed.), Global Wetlands: Old World and New, Elsevier Science B.V., 1994, pp. 215-234.

[10] J.-C. Lefeuvre, V. Bouchard, E. Feunteun, S. Grare, P. Laffaille, A. Radureau, European salt marshes diversity and functioning: the case study of the Mont Saint-Michel bay, France, Wetland Ecology and Management 8 (2000) 147-161.

[11] C. Lévêque, Ecologie, de l'écosystème à la biosphère, Masson Science, Dunod, Paris, 2001.

[12] F.E. Clements, Plant Succession, Carnegie Institute, Washington, 1916.

[13] R.H. McArthur, E.O. Wilson, The Theory of Island Biogeography, Princeton University Press, Princeton, 1967.

[14] K.S. Dijkema, W.G. Beeftink, J.P. Doody, J.M. Gehu, B. Heydemann, S. Rivas Martinez, Salt marshes in Europe, Report Council of Europe, Nature and Environment Series 30, Strasbourg, 1984.

[15] J.M. Gehu, Étude phytocoenotique analytique et globale de l'ensemble des vases et pré salés et saumâtre de la façade Atlantique Française, Rapport de synthèse, Ministère de l'Environnement, Paris, 1979.

[16] R.T. Kneib, The role of tidal marshes in the ecology of estuarine nekton, Oceanography and Marine Biology: an Annual Review 35 (1997) 163-220.

[17] P. Laffaille, E. Feunteun, J.-C. Lefeuvre, Composition of fish communities in a European macrotidal salt marsh (The Mont Saint-Michel bay, France), Estuarine, Coastal and Shelf Sciences 51 (2000) 429-438.

[18] P.C. Dias, Sources and links in population biology, Trends in Ecology and Evolution 11 (1996) 326-330.

[19] M. Amanieu, Recherches écologiques sur les faunes des plages abritées et des étangs saumâtres de la région d'Arcachon, $\mathrm{PhD}$ dissertation, University of Bordeaux, France, 1967. 
[20] B. Elkaim, H. Rybarczyk, Structure du peuplement des invertébrés des zones halophiles de la baie de Somme (Manche Orientale), Cah. Biol. Mar. 41 (2000) 295-311.

[21] P. Fouillet, Evolution des peuplements d'arthropodes des shorres de la Baie du Mont Saint-Michel, PhD dissertation, University of Rennes 1, France, 1986.

[22] P. Duncan, A.J.M. Hewison, S. Houte, R. Rosoux, T. Tournebize, F. Dubs, F. Burel, V. Bretagnolle, Longterm changes in agricultural practices and wildfowling in an internationally important wetland, and their effects on the guild of wintering ducks, Journal of Applied Ecology 36 (1999) 11-23.

[23] M.C. Eybert, T. Geslin, S. Questiau, E. Feunteun, Shorebird community variations indicative of a general perturbation in the Mont-Saint-Michel Bay (France), C. R. Biologies 326 (2003) S140-S147.

[24] J.P. Gibbs, Wetland loss and biodiversity conservation, Conservation Biology 14 (2000) 314-317.

[25] M.W. Schwartz, C.A. Brigham, J.D. Hoeksema, K.G. Lyons, M.H. Mills, P.J. van Mantgem, Linking biodiversity to ecosystem function: implications for conservation ecology, Oecologia 122 (2000) 297-305.

[26] K.S. McCann, The diversity-stability debate, Nature 405 (2000) 228-233.

[27] D. Tilman, J.A. Downing, Biodiversity and stability in grasslands, Nature 367 (1994) 363-365.

[28] S. Naem, L.J. Thompson, J.H. Lawler, J.H. Lawton, R.M. Woodfin, Biodiversity and ecosystems functioning: empirical evidence from experimental microcosms, Philosophical Transactions of the Royal Society, London B 347 (1995) 249262.

[29] J.H. Steele, Marine functional diversity, Ocean and land ecosystems may have different time scale for their responses to change, BioScience 41 (1991) 470-474.

[30] J. De Leeuw, W. De Munck, H. Olff, J.P. Bakker, Does zonation reflect the succession of salt marsh vegetation? A comparison of an estuarine and a coastal bar island marsh in the Netherlands, Acta Bot. Neerl. 42 (1993) 435-445.
[31] J.P. Bakker, Nature management by grazing and cutting, in: Geobotany, Vol. 14, Kluwer Academic Publisher, Dordrecht, 1989.

[32] K. Kiehl, I. Eischeid, S. Gettner, J. Walter, Impact of different sheep grazing intensities on saltmarshes in northern Germany, Journal of Vegetation Science 7 (1996) 99-106.

[33] H. Olff, M.E. Ritchie, Effects of herbivores on grassland plant diversity, Trends in Ecology and Evolution 13 (1998) 261-265.

[34] V. Schricke, Distribution spatio-temporelle des populations d'anatidés en transit et en hivernage en baie du Mont SaintMichel en relation avec les activités humaines, $\mathrm{PhD}$ dissertation, University of Rennes 1, France, 1993.

[35] P. Laffaille, S. Brosse, E. Feunteun, A. Baisez, J.-C. Lefeuvre, Role of fish communities in particulate organic matter fluxes between salt marshes and coastal marine waters in the Mont Saint-Michel bay, Hydrobiologia 373/374 (1998) 121-133.

[36] J.-C. Lefeuvre, P. Laffaille, E. Feunteun, Do fish communities function as biotic vectors or organic matter between salt marshes and marine coastal waters?, Aquatic Ecology 33 (1999) 293-299.

[37] P. Laffaille, J.-C. Lefeuvre, M.T. Schricke, E. Feunteun, Feeding ecology of 0-group sea bass, Dicentrarchus labrax, in salt marshes of the Mont Saint-Michel bay (France), Estuaries 24 (2001) 116-125.

[38] P. Laffaille, Ichtyofauna/macrotidal salt marsh relationships: the example of the Mont Saint-Michel bay, Cybium 25 (2001) 295-296.

[39] P. Laffaille, J.-C. Lefeuvre, E. Feunteun, Impact of sheep grazing on juvenile sea bass, Dicentrarchus labrax L., in tidal salt marshes, Biological Conservation 96 (2000) 271-277.

[40] V. Bouchard, F. Digaire, J.C. Lefeuvre, L.M. Guillon, Progression des marais salés à l'ouest du Mont-Saint-Michel entre 1984 et 1994, Mappemonde 4 (1995) 28-34.

[41] L. Valéry, Progression d'Elytrigia aetherica dans un marais salé : incidence sur les flux de matière organique, Rapport DEA, Muséum National d'Histoire Naturelle, France, 2001.

[42] Q.C.B. Cronck, J.L. Fuller, Plant Invaders, Chapman \& Hall, 1996. 